\title{
Exploration and Practice of Teaching Reform of Computer Basic Course in Colleges and Universities
}

\author{
Xin Sui \\ College of Humanities and Sciences of Northeast Normal University, Changchun, China, 130117
}

Keywords: university computer foundation; computer technology; teaching quality; reform and practice

\begin{abstract}
The university computer foundation is a general course of computer science for students of non-computer majors in colleges and universities. With the rapid development of computer technology, computer-related new concepts and new knowledge are emerging. Public course teachers should constantly learn new knowledge, renew teaching contents and try teaching reform. The ultimate goal is to focus on students, focus on developing students' practical ability, improve their employability and improve their teaching quality. This paper analyzes the current situation and problems of computer basic teaching in colleges and universities. The reform and practice of university computer basic course are explored, and the basic curriculum system of university computer based on the integration of various disciplines is constructed so as to better promote students' study of professional subjects.
\end{abstract}

\section{Introduction}

\subsection{Analysis of the Basic Computer Course in Colleges and Universities}

University computer is a public basic course for non-computer majors. It is a combination of knowledge, skill and application. It is based on practice, learning experience in the process of learning knowledge, learning knowledge in the process of practice.

\subsection{The purpose of the course}

The purpose of setting up university computer courses is to provide students with computer knowledge, ability and quality education, to enable students to have the corresponding computer basic application ability, to cultivate the basic information literacy of the students, to master the computer, network and related technology and basic knowledge. [1] It can draw lessons from and introduce some concepts, techniques and methods in Computer Science in the future professional study.

\subsection{The effectiveness of the curriculum}

Through the study of this course, we can improve students' computer literacy. To make the students understand the hardware structure and composition principle of the computer, be familiar with the typical application fields of the computer, be familiar with the basic functions of the computer and its operating system, master the use of the operating system, and the use of office software and the basic operation of the common tool software; master the basic technology of the network; information retrieval and profit. Use in the same field. [2] Training students' practical operation skills lay a necessary foundation for subsequent professional basic courses and professional backbone courses.

\section{Analysis on the Current Situation of University Computer Basic Course}

\subsection{The subject of teaching is no longer a "zero basis"}

With the renewal of basic education concept in primary and secondary schools, computer 
education has been widely popularized in primary and secondary schools. As well as the rapid development of information technology, more and more college students have a certain ability of computer application. [3] Some of them may be the master of computer operation.

\subsection{Obsolete teaching methods}

The basic computer courses in most colleges and universities are still used in the traditional computer room, and the teacher's demonstration operation is the main course. [4] Teachers explain knowledge points step by step, and students passively accept knowledge. Students' interest in learning is not high, participation is low, and learning initiative is not high.

\subsection{The uneven level of students}

Most students simply edit simple texts. Some students may not even grasp some basic operations, such as basic skills of typing, basic fingering, etc. [5] Some students do not know how to make full use of the Internet to obtain useful information resources, but to make use of internet entertainment only.

\subsection{The content of the course is not closely related to the student's major}

The existing university computer foundation for non-computer majors only allows students to acquire computer related skills, and does not surpass the technology of the computer itself to assist students in professional learning.

With "student centered, teacher led", we should educate students according to social needs, professional development and innovation, so as to achieve the goal of "teaching people to fish".

\subsection{The unreasonable way of evaluation}

The traditional method of curriculum evaluation adopts the final written examination. In fact, computer application is mainly based on operation. Simple written examination is not good enough to check students' mastery of knowledge. It cannot fully mobilize the enthusiasm of students, and does not meet the training objectives of the curriculum.

\section{Exploration on the Reform of University Computer Course}

\subsection{Take computer thinking as a breakthrough point, and conduct in-depth teaching of computer basic courses}

In March 2006, Professor Zhou Yizhen put forward the concept of computational thinking. In 2010, the nine school alliance took the cultivation of computational thinking ability as the core task of computer basic education. It is the goal of Computational Thinking to train non computer majors to form a completely new thinking mode through learning computer knowledge and technology.

Computational thinking should be carried out in the basic computer course system of universities instead of just one course. Strengthen the typesetting and writing standard of the paper, the production skills of the presentation, and enhance the ability of information retrieval.

In the teaching process, we should pay attention to the teaching of computational thinking, enhance the transformation from thinking to ability, and echo with other professional basic courses and main courses. Usually in grade two, database technology courses are set up, and programming is the focus of computational thinking. Although computational thinking is more than programming, the final realization depends on programming. [6]

\subsection{Teach students in accordance with their aptitude in stratified teaching}

Educators should carry out teaching activities according to the actual situation of students and individual differences. The subjects of the university computer course are freshmen. After freshmen are enrolled, they are tested thoroughly. According to the score, the students are divided into three grades: A, B and C, and grade A is the best. Different classes are made up of different grades. [7]

Different teaching objectives should be formulated according to different grades, and different evaluation criteria should be adopted. For poor students, teaching goals can be reduced, and final 
tests will be less difficult. Set a higher teaching goal for the students with better foundation, and the usual test can also improve the difficulty and depth of the test questions. [8] For different levels of students, they should consult different standards when checking their usual assignments and tests.

In the course of learning, comprehensive tests are carried out regularly. Students who reach A-level can join A classes. Similarly, a class students who fail to meet the test requirements may also transfer to $\mathrm{B}$ or $\mathrm{C}$ classes.

Adopting a dynamic teaching class management mechanism is conducive to stimulating students' interest in learning and making progress and improving their ability and level.

\subsection{Case teaching to increase interaction between teachers and students}

The teaching content is divided into modules and case teaching. For example, before learning PowerPoint software, we first broadcast outstanding PPT works over the years to stimulate students' interest in learning. Let the students take the initiative to learn.

In class, the teacher divided the students into the learning group, each group arranged different learning tasks. After that, the groups were displayed, explained, before the group commended each other, and the teachers summarized and summed up. Students really participate in teaching activities and become the leaders of learning.

After learning a module, the work is displayed. After finishing PPT, he organized the PPT competition to promote teaching and enhance students' enthusiasm for learning.

\subsection{Compiling textbooks for students}

Using modules as units to compile teaching materials, we do not need to traditionally compile textbooks according to the classification of chapters. Each module is a complete and independent knowledge system. The contents related to teaching activities should be organized into knowledge modules. Each module is determined according to the teaching objectives of the course, and each module is targeted at a specific skill. Let students know clearly how to do, how to learn and how to learn better.

The modular teaching material is more helpful to improve the students' learning ability, improve the quality of teaching, and better promote the learners to internalize knowledge and better apply to the actual life.

\subsection{Carry out mixed online and offline teaching}

MOOC (massive open online course) has the advantages of rich teaching resources, flexible learning methods, and equal education and so on. But its high registration rate and low completion rate are also undeniable facts.

SPOC (Small Private Online Course) restricts the learner's condition and teaches small classes. SPOC really realized the students as the main body. Students actively explore learning through online learning, class interaction, and many other ways. A variety of teaching resources are distributed to the teaching platform, and students learn the corresponding theoretical knowledge through network teaching.

The teacher made the teaching video of the basic knowledge and basic operation of the basic computer course. [9] Many kinds of teaching resources are released to the teaching platform. Students learn relevant theoretical knowledge through network teaching. In class, teachers first ask questions pertinent to students, and examine the situation of autonomous learning before class. The teacher objectively evaluated the students' learning effect and focused on the difficult problems. After class, students start the thematic discussion through the network teaching platform. Teachers' summarization of knowledge system focuses on answering students' doubts. [10]

According to the problems in the actual teaching process, teachers can adjust the teaching progress and integrate teaching activities at any time, so as to better achieve the teaching objectives.

\section{Conclusion}

In recent years, some new ideas and technologies have been emerging, which have a profound 
impact on the reform of computer basic courses. The basic course of university computer is mainly aimed at improving students' computer application ability and cultivating compound and applied talents.

The computer science has developed rapidly and the knowledge is updated quickly. [11] It is required that teachers should have comprehensive computer technology, renew teaching ideas, enrich and perfect themselves, try new innovation and innovation, and then achieve the ultimate goal of higher education.

\section{Acknowledgement}

This work was financially supported by the "The Research on the Flip Classroom Teaching Model Based on MOOC+SPOC" (ZD16071); the periodical research results of higher education research in the 2016 of Jilin Province (JGJX2016B27);2016 Annual study on the teaching reform of higher education in Jilin Province "Research and Practice of SPOC Teaching Mode".

\section{References}

[1] Li Qiongyuan, Tang Applied Technology University Computer Basic Course Teaching Reform of contemporary research group [J]. journal, 017 (10): 4-5.

[2] Zou Ling. Exploration of teaching reform of computer basis in University. [J]. Forum on education and teaching, 2017 (45): 113-114.

[3] Zhu Wei. Teaching reform of computer public courses in universities, [J]. education modernization, 2017,4 (49): 121-123.

[4] Jiang Xiaoqing, Liu Weimin, Yang Lei, Shaw. Research on the reform of the teaching model of University Computer Foundation Based on the overturned class [J]. China education informatization, 2017 (19): 72-75.

[5] Sui Xin. Research and practice of college computer Basic course reform under the talent training model [J]. Journal of Jilin Province Institute of Education, 2016,32 (10): 65-67.

[6] Zhang Cheng. A discussion on the teaching reform of the course of the computer foundation of the University of Contemporary University [A]. Beijing International Academy of science and technology, the first International Symposium on the construction of international information technology (1) [C]. Asahi Huaxia (Beijing) International Academy of science and technology: 2016:2.

[7] Su Zhong bin, Liu Wenyang. Computer centered curriculum reform in agricultural colleges and universities centered on Computational Thinking. [J]. teaching in Chinese universities, 2015 (08): 55-57.

[8] Sui Xin. A study on the teaching mode of the inverted classroom based on SPOC [J]. Journal of Jilin Provincial Institute of Education, 2017 (5): 149-151.

[9] Lu Hangwei, Li Qing, Tian Maoyi. Practice of computer experimental teaching reform based on the characteristics of micro class [J]. experimental technology and management, 2017,34 (01): $175-177+180$.

[10] Huang Hui. Based on Computational Thinking, the teaching reform of computer basic courses in universities, [J]. computer knowledge and technology, 2017,13 (35): 194-195.

[11] Zhao Yaochi, Hu Zhuhua, Chen Mingrui, Peng Jinlian. Research on the teaching reform of the computer based curriculum for computer based on computing thinking [J]. Journal of Hainan University (NATURAL SCIENCE EDITION), 2014,32 (04): 383-388. 